\title{
Sayyid Mumtaz Ali and 'Huquq un-Niswan': An Advocate of Women's Rights in Islam in the Late Nineteenth Century
}

\author{
GAIL MINAULT
}

University of Texas at Austin

Sometime in the late I 8gos, Sayyid Mumtaz Ali visited Aligarh and happened to show Sir Sayyid Ahmad Khan the manuscript of his treatise in defense of women's rights in Islamic law, Huquq un-Niswan. As he began to read it, Sir Sayyid looked shocked. He then opened it to a second place and his face turned red. As he read it at a third place, his hands started to tremble. Finally, he tore up the manuscript and threw it into the wastepaper basket. Fortunately, at that moment a servant arrived to announce lunch, and as Sir Sayyid left his office, Mumtaz Ali snatched his mutilated manuscript from the trash. He waited until after Sir Sayyid's death in 1898 , however, to publish Huquq un-Niswan. ${ }^{1}$

What was this manuscript that so aroused Sir Sayyid's ire and who was its author? Sayyid Mumtaz Ali (1860-1935) is chiefly known for his pioneering role in Urdu journalism for women. ${ }^{2} \mathrm{He}$ founded the weekly newspaper Tahzib un-Niswan in Lahore in 1898 together with his second wife, Muhammadi Begam (1878?-1908). From this, it might be assumed that Mumtaz Ali was a western-educated Muslim, perhaps a product of Aligarh College, with only a rudimentary knowledge of Islamic doctrine and little qualification to write a treatise on Islamic law. Such, however, was far from the case, for Mumtaz Ali was a Deobandi, with a thorough education in the Islamic sciences. His

\footnotetext{
' Abu Athar Hafiz Jalandhari, 'Maulvi Sayyid Mumtaz Ali,' Tahzib un-Niswan $3^{8}$ (6 July r 935): 6I 5 $^{-1}$ 6; Sayyid Mumtaz Ali, Huquq un-Niswan (Lahore: Dar ul-Isha'iat-ePunjab, 1898 ), hereafter cited as HN.

2 There is no biography of Mumtaz Ali. The following account is based upon: Sayyid Mumtaz Ali, 'Tahzib un-Niswan,' in Tahzib un-Niswan (hereafter cited as TN) 21 , Jubilee Number (6July I 9 I8) : 424-33; Hafiz Jalandhari, 'Maulvi Sayyid Mumtaz Ali,' TN (6 July 1935): 607-17 (originally published in 1927 in Makhzan, this article was reprinted in TN as an obituary); and interviews with the descendants of Mumtaz Ali in Lahore in 1977.

$0026-749 \mathrm{X} / 90 / \$ 5.00+.00 \quad$ C) 1990 Cambridge University Press
} 
family was closely associated with the founders of the Deoband school and the intellectual legacy of Shah Waliullah of Delhi. His father, Sayyid Zulfiqar Ali, came from Saharanpur district and had studied in Delhi in the years before the 1857 revolt with Maulana Mamluk Ali Nanautawi. One of his fellow students was another Zulfiqar Ali from Deoband, later a founder of the Deoband madrasa and father of Mahmud al-Hasan Deobandi, known as the Shaikh al-Hind. Sayyid Mumtaz Ali and Mahmud al-Hasan were also friends and contemporaries who studied together at Deoband under Mamluk Ali's successors, Maulanas Muhammad Yaqub and Muhammad Qasim Nanautawi. Mumtaz Ali did not complete his education at Deoband, but his connection with the tradition of Islamic reform institutionalized at its madrasa is clear.

Mumtaz Ali's education began at an Arabic maktab in Deoband and proceeded in the Punjab, where his father was in government service. He studied the Quran, Arabic grammar, Persian literature, fiqh (law), and mantiq (logic). At the age of thirteen, he returned to Deoband, where he studied the Islamic sciences at the madrasa, with an emphasis on Quran and hadith. After a year or two, he rejoined his father in the Punjab, was tutored in English, and attended Lahore Government High School. In Lahore, he became involved in the religious debates among Muslims, Christian missionaries, and members of the Arya Samaj that were raging at that time, and read the works of munazarah (religious disputation) written by such leading Muslim spokesmen as Maulana Rahmatullah Kairanwi and Maulana Sayyid Abul Mansur Dehlawi. ${ }^{3}$ In 1884 he failed his BA exams, probably as a result of his religious preoccupations. He then took a job as a translator in the Lahore High Court, but continued to write and publish religious pamphlets. In 1879 he had begun corresponding with Sir Sayyid Ahmad Khan, who was impressed by the young man and eventually invited Mumtaz Ali to visit him to discuss religious matters. Sir Sayyid's avuncular interest in Mumtaz Ali's career lasted until the end of Sir Sayyid's life, although they obviously did not agree in all matters, as the above episode makes clear.

${ }^{3}$ Rahmatullah Kairanwi was the chief adversary in debate of the missionary, Pfander, in Agra in the 1850 os. Sayyid Abul Mansur Dehlawi was the leading Muslim spokesman in the Shahjahanpur debates among Christians, Muslims, and Arya Samajis in $1875-76$. For further details on the religious debates in North India in the mid-nineteenth century, see A. A. Powell, 'Maulana Rahmat Allah Kairanwi and Muslim-Christian Controversy in the mid-19th Century,' JRAS (1976): 42-63; and Barbara Metcalf, Islamic Revival in British India: Deoband, 1860-1900 (Princeton, 1982), pp. $19^{8-234}$. 
Mumtaz Ali's work, Huquq un-Niswan, which so irritated Sir Sayyid, showed the influence of munazarah in its style, and in content, it was a logical extension of a number of concerns of the Deoband ulama of the time. The Deobandis were anxious to improve the knowledge of Islamic law in the Muslim community in general, and to promote the observance of the injunctions of Islam in the personal lives of Muslims. To that end, the Deoband madrasa founded a department of Islamic legal rulings, the dar al-ifta which issued fatawa in response to queries from Muslims all over India. ${ }^{4}$ In addition, the Deobandi ulama wanted to combat the observance of traditional customs which they felt were un-Islamic. For that reason they showed some interest in the education of women, at least to the extent of improving their knowledge of Islam, since women were the prime practitioners of a host of rituals and customs that the reformers abominated. Best known of the Deobandi writings for women was Maulana Ashraf Ali Thanawi's Bihishti Zewar. ${ }^{5}$

Mumtaz Ali's treatment of women's rights in Islam, however, is considerably more advanced in spirit than that of either his Deobandi intellectual mentors or of Sir Sayyid. ${ }^{6}$ Personal factors doubtless played a role in the development of his attitudes toward women's rights. For one thing, his contact with Christian missionaries in religious debate in Lahore raised issues of cultural pride. The missionaries criticized Islam (and other Indian religions) for the low status they gave to women and blamed religion for the lack of education among women as well. Mumtaz Ali knew that the position of women in Islamic law was theoretically much higher than their current status was in fact. The cause of this discrepancy between the legal position of Muslim women and the actual facts of their lives in India, he felt, must be adherence to false customs. Not only women, but also and especially men, felt that keeping women in ignorance was part of their religion. To combat such a view, he wrote Huquq un-Niswan.

Another reason for Mumtaz Ali's concern about women's status was even more personal. An educated man, he had married a woman who was probably uneducated, since he tried to teach her to read and write. ${ }^{7}$ She died in the mid-I8gos, leaving him a widower with two young children to raise. His subsequent marriage to Muhammadi Begam, a

4 Metcalf, Islamic Revival, p. 146.

${ }^{5}$ Barbara Metcalf, 'Islam and Custom in Nineteenth-Century India: The Reformist Standard of Maulana Thanawi's Bihishti Zewar,' Contributions to Asian Studies, XVII, pp. $62-78$.

${ }^{6}$ Sir Sayyid felt that a rudimentary education was quite enough for women, see below, note 15 .

${ }^{7}$ Hafiz Jalandhari, 'Maulvi Sayyid Mumtaz Ali,' TN (6 July r935): 614-15. 
woman who had some education, led to the founding of the journal Tahzib un-Niswan. Mumtaz Ali thus had personal experience with women's education, and his bereavement had doubtless also helped focus his attention on the importance of women, not only as nurturers of the young, but also as companions to their husbands.

Huquq un-Niswan thus emerged from Mumtaz Ali's training in Islamic law and his experience of religious debate, his sense of cultural pride when faced with an external challenge, his acute awareness of the need for internal reform, and his personal anguish of bereavement and desire for an educated wife. The treatment of women's rights in Islam as expressed in Huquq un-Niswan was not only surprising for its time, but seems enlightened even by today's standards. At the outset, Mumtaz Ali states that people will probably attack him for blindly following the English, ${ }^{8}$ but that is not the case. Anyone who knows the shari ${ }^{6}$ at and who follows the example of the Prophet and his family must be prepared to reject ignorant customs. He thus places himself firmly within the framework of Deobandi reform, seeking to revalidate Islamic law and the prophetic example in Muslim daily life, and to eradicate customary accretions that are superstitious, wasteful of human potential or resources, and otherwise ill-informed and unIslamic. Deoband sought to equip the modern Muslim with a reformulation of the fundamentals of his faith. ${ }^{9}$ Mumtaz Ali sought to equip Muslim women with a reaffirmation of their equality with men as human souls and with a reformulation of the fundamentals of their rights in Islamic law. Without such a reformulation, Mumtaz Ali feared for the health of the Muslim family, and with it, the Muslim community as a whole. He states that keeping women in ignorance and isolation is not a requirement of Islam, and to say that it is betrays a lack of understanding of religion as well as a fundamental mistrust of women which is destructive of family life, of human love, and of all that the Prophet stood for in a dynamic, just human society. ${ }^{10}$

\section{Huquq un-Niswan: Women's Rights in Islam}

The balance of this article will summarize the contents of Huquq unNiswan, give the main lines of Mumtaz Ali's argument, characterize his style, and comment upon the significance of the work. Reading through

\footnotetext{
${ }^{8}$ His phrase is Angrezon ki taqlid.

${ }^{9}$ Metcalf, Islamic Revival, pp. $11-12$.

${ }^{10} \mathrm{HN}$, pp. 3-4.
} 
Huquq un-Niswan, one is impressed by its careful organization, its logical step-by-step argument, and its rationality in dealing with a subject that is close to people's intimate lives and emotions. In style, it is like a debate, setting out the various arguments that his opponents might use, and knocking them down one by one. Its language is simple and straightforward. In fact, in all his works, Mumtaz Ali takes care to write clearly and to define words, especially those from Arabic, that might offer difficulty to his readers. Throughout this work, he quotes copiously from the Quran and hadith to support his arguments, but he is always careful to translate and interpret these passages as he goes along. He writes both to convince men that women should be recognized as fully-fledged, equal human beings and given their rights, and to communicate with women, who might not know any of the abstruse terminology. ${ }^{11}$

The work is divided into five parts: ( $I$ ) the various reasons why people say that men are superior to women, (2) women's education, (3) purdah, (4) marriage customs, and (5) relations between husband and wife. The first section, an examination of the reasons why men are considered superior to women, is a tour de force. It involves Quranic and hadith commentary, discussion of points of Islamic law, and basic psychological assumptions. It is rigorous, logical, and convincing. Of course, whether Mumtaz Ali convinces his opponents that women are not inherently inferior to men is open to question, since, as he admits, the opposing arguments are falsely considered an intrinsic part of religion and hence are hard to shake by rational argument. Nevertheless, Mumtaz Ali would be a formidable opponent in debate.

\section{Men's Supposed Superiority over Women ${ }^{12}$}

He begins his discussion by pointing out that though men and women have different physiques and thus fulfill different biological functions, they are nevertheless both human beings, and hence equal in God's sight. All arguments for male superiority derive either from this biological difference, or else from ignorance of the true message of Islam. He lists the arguments for keeping half the human race in

"The Urdu word used to describe his style is salis: easy, simple, clear, not abstruse. At one point, Mumtaz Ali uses the term maulviana to describe difficult Urdu style, as contrasted with the style he wished to achieve. Mumtaz Ali, 'Tahzib un-Niswan,' TN (6 July 1918 ): 430 .

${ }_{12}$ This section summarizes $\mathrm{HN}$, Pp. 3-42. 
bondage as follows: ( $\mathrm{I}$ ) God gave men greater physical strength, thus in matters where strength is important, including the capacity to rule, men are superior. (2) Men's intellectual powers are also superior to those of women. (3) Men are superior in religious matters, for God has sent only male prophets, not prophetesses. (4) Verses of the Quran are frequently cited in support of male dominion over women. (5) God first created man and then created woman to serve him. (6) In the Quran, it states that the testimony of two women is equal to that of one man, and in the inheritance of property, a daughter's share is only half that of a son, hence women are inferior in these respects. (7) Men may have as many as four wives at once, thus clearly, God gave men more powers. (8) Even in the after life, women have an inferior position, for God granted that men will be kept company by beautiful women (houris), but women shall be chaste in paradise.

Mumtaz Ali then considers each of these arguments in turn, in order to determine whether they are based on reason and thus truthful, or whether they are irrational and thus falsehood. First, no one can deny that men have greater physical strength, but one must also realize that this does not automatically give men the right to lord it over women. Men can cut down trees or cut people's throats; they are naturally suited to jobs that require physical strength. But does the ability to do such things give men greater nobility or true superiority as compared to women? A donkey can carry more on its back than a man, but that does not mean that donkeys are superior to men. As for who has the right to rule, physical strength is not the only capacity that counts. Perhaps, in the dark ages, it was correct to say that 'might makes right.' But with the advance of civilization and the founding of kingdoms with laws and other institutions of government, it is more important for the ruler to have understanding and compassion in order to enjoy the confidence of the ruled. Hence the right to rule belongs not to the strong, but to the wise. Further, when women have been called upon to rule, as in the case of the current Queen-Empress, Victoria, they have ruled with great skill, wisdom, and justice.

The second argument, that of greater intellectual capacity, is also without basis. 'Man,' in the sense of 'human,' is higher in intellectual capacity than other animals, but men and women are of the same species and thus must be compared to other animals as one. There is no necessary connection between greater physical strength and greater rationality or intellectual power. Any differentiation between the brain powers of the two genders must be something that society has attributed to them, not that God has granted. Indeed, if the intelligence 
of women were less than that of men, the human race would rapidly become stupid, for intelligence would be transmitted in lesser degree to each succeeding generation.

As for the religious reason, that there has never been a woman prophet, Mumtaz Ali dismisses it by saying that the extant names of the prophets in the scriptures are all men, but there are thousands of prophets whose names have not survived, and who is to say that there are no prophetesses among them? On the more serious question of the greater spiritual strength of men, he points out that one cannot compare all men to all women in spiritual matters. Just as some men are more spiritual than most women, so too are some women more spiritual than most men. He gives as examples Hazrat Amina and Hazrat Fatima, the mother and daughter of the Prophet Muhammad, and Rabia of Basra, the mystic poet.

The main reason for putting men in authority over women, however, is the frequently cited verse of the Quran:

Men are the managers of the affairs of women
for that God has preferred in bounty
one of them over another, and for that
they have expended of their property.
Righteous women are therefore obedient ...

Mumtaz Ali disagrees with the usual supremacist interpretation of these verses. Analyzing the original Arabic, he states that it is by no means clear who has different qualities from whom. It may mean that some human beings have higher qualities (bounty) than others, but not necessarily men over women. Probably sensing that this was not a very strong argument, Mumtaz Ali then hazards the view that this verse deals with areas where men do have greater authority (business and property management), but does not mention areas where women are more competent (responsibility for children, servants, the household). Hence, one cannot generalize from this verse that women should be subordinate to men in all things.

The argument that Adam was created first and Eve second and that this proves his superiority is unworthy of serious consideration, says Mumtaz Ali. One could as easily argue that God did not want women to be alone, so for her protection and happiness, He created man first.

In the matter of court witnesses, where two women's testimony is equal to that of one man, Mumtaz Ali points out that this verse in the Quran refers specifically to business matters, in which women may

${ }^{13}$ This translation is by A.J. Arberry, The Koran Interpreted, I (New York: Macmillan, 1955), p. 105 . 
have less experience. But their lack of experience is a product of social conditions, not an inherent defect. In testimony over marriage, divorce, adultery-matters where women are just as experienced as men-the Quran makes no distinction. Mumtaz Ali goes on to cite hadith in support of his argument that there are cases in which one woman's testimony can be decisive, for example: the case where a woman served as wet nurse to a boy and girl who later married. Only she would be in a position to confirm that the marriage was incestuous in Islamic law. Hence, to say that a woman's testimony is unequal to that of a man is a misreading of Islamic law and deprives half of humankind of legal rights.

In matters of inheritance, it is true that a daughter inherits only half the share that a son inherits. But one can argue that a daughter may take a dowry from her paternal home at the time of marriage, and, in addition, she is entitled to mahr (dower) from her husband, so an unequal portion in inheritance is only just to her male siblings. However, this provision in no way implies unequal rights to property, and it certainly should not be used to argue that the daughter is inferior to the sons.

Mumtaz Ali also subjects the polygyny argument, that a man may take four wives at a time, to intense scrutiny. He argues that the Arabic text permits four wives, but once again, it is not clear whether it means one at a time, or as many as four simultaneously. He tends to favor the first interpretation, that a man, if widowed or divorced, may remarry up to four times. On the other hand, Mumtaz Ali also argues that if a man does wish to remarry while still married to his first wife, he must seek her permission. He cites hadith to support this contention, which seems to go against his first interpretation, above. He also notes that various schools of Islamic law permit stipulations in marriage contracts forbidding polygynous remarriage, or making divorce automatic in the event of a husband's remarrying. This ruling confirms the necessity for the husband to obtain the wife's permission before remarriage. Mumtaz Ali's position on the polygyny issue, while somewhat inconsistent, nevertheless makes a point concerning male and female status: Men cannot simply do as they please without consulting the women involved, and hence the women are not mere chattels, but full partners in a contractual agreement, marriage. Thus, the polygyny argument is no proof of male superiority.

Finally, concerning the houris of paradise, Mumtaz Ali argues that although in the Quranic verse, all the pronouns referring to 'the believer' are masculine, stating that 'he' will find a spouse in heaven, 
the true meaning of the verse is that when 'one' goes to paradise, he/she will find his/her spouse there. If this grammatical analysis has not convinced his reader, Mumtaz Ali goes on to point out that, in any case, believers who enter paradise will have changed their essence, and to the soul, all distinctions of gender are meaningless.

Having disposed of these arguments, Mumtaz Ali maintains that the intellectual superiority of men has in no way been proven, and, in fact, experience shows that girls, if given the chance, are often quicker and more diligent students than boys. He notes that some boys go to school and derive very little benefit from it, whereas their sisters, without any formal education, may learn to read and write through perseverance. As for moral strength, he maintains that here, too, women have the edge. He gives as an example the plight of widows in India. In spite of the fact that the Quran grants widows the right to remarry, Muslims as well as Hindus consider this a great scandal. On the other hand, widowers readily remarry. Women therefore are expected to show greater self-sacrifice in this matter, as in so many others. Is that not evidence of their greater moral fiber?

This analysis of the first section of Huquq un-Niswan gives some indication of Mumtaz Ali's method. He combines Quranic and hadith commentary with logical argumentation and a certain amount of sociological acumen, the whole conveyed in a straightforward Urdu style. His position is clearly reformist, even revolutionary, in the context of his times. He shows that the distinctions made between men and women that are justified on religious grounds are, in fact, the products of social custom. If these distinctions are subjected to the cold scrutiny of reason, well bolstered by a knowledge of the religious sciences, the fallacy and injustice of male supremacy becomes clear.

\section{Women's Education ${ }^{14}$}

Mumtaz Ali continues in this vein through the succeeding sections of the work. In his discussion of women's education, he starts from the Quranic injunction that both Muslim men and women should seek knowledge. This clearly indicates that, in God's eyes, men and women have equal intellectual powers that should be developed. Men make the mistake of considering themselves superior to women, and then they make the second mistake of considering women incapable of intellec-

14 This section summarizes HN, pp. 42-6o. 
tual attainments, and thus deprive them of the education that could prove otherwise. Social custom is thus to blame for the fact that women are uneducated and locked up like prisoners-this is not what God intended.

The question is not whether women should be educated, but what kind of education they should have and how much. Many people say that if a woman knows how to say her prayers properly, and how to cook and sew and take care of children, that is enough; more education than that is dangerous and will cause her to be disobedient. That view, says Mumtaz Ali, is baseless. One can only judge whether something is beneficial or dangerous by seeing its effects upon the world, so how can one say that women's education is dangerous if one has not given it a chance? The danger comes, not from giving women an education, but rather from depriving them of a chance for full moral and mental development. In order to be aware of her moral rights and duties in Islam, a woman needs to know more of her religion than simply saying her prayers. Similarly, in order to raise children, to run a home, and to be a life's companion to an educated man in this day and age, she needs more than a rudimentary education. An inadequately educated woman cannot raise her children properly and thus the entire society suffers. Her husband takes no pleasure in her company and thus may go astray, seeking out the company of courtesans. For the survival of the Muslim family and of Muslim civilization as a whole, therefore, the education of women to their fullest potential is necessary. ${ }^{15}$

Mumtaz Ali then takes up the question of what kind of education is appropriate for women, and here, too, he argues for a broad, humanistic education, not a narrow, household-centered one. Based on his assumption that men and women are both human beings and thus have equal rational and moral faculties, he argues that one cannot say that something is good for men and dangerous for women. Education is productive of a heightened moral and ethical sense as well as increased practical knowledge; this is as true for women as it is for men. If a book is deleterious, it is equally so for men and women. Thus if a book is inappropriate in the zanana (women's quarters), it should not be

${ }^{15}$ In his arguments in favor of women's education, Mumtaz Ali responds directly to a number of arguments against it, but he is also responding indirectly to the position of Sir Sayyid Ahmad Khan, which was that women's education was premature, given the then current backward state of men's education among Muslims. Mumtaz Ali did not agree, but doubtless out of respect for Sir Sayyid, he does not mention that view here. Later on, however, after he establishes his case in favor of an equal education for boys and girls, he quotes a letter from Sir Sayyid giving the elder man's position. HN, pp. $57-9$. 
permitted in the diwan khana (men's quarters) either. It follows that books appropriate for the education of boys are also appropriate for girls' education. Girls should be able to read, understand, and comment upon the Quran, not just parrot it without comprehension. They should read and write Urdu with good style, which means reading books in Urdu and Persian that serve as good models of style. They should read ethical works, and Indian and English history for their ethical lessons. They should know mathematics and science in order to manage household accounts and to be able to explain such phenomena as the changing seasons, phases of the moon, thunder and lightning. Knowledge of history, geography, literature, and science (all conveyed in the Urdu medium) is also necessary in order for them to be able to understand their husbands' interests and preoccupations and to direct their children's education.

To bolster his argument, Mumtaz Ali quotes a letter from an educated woman which is a model of good Urdu style and which also shows the crucial importance of women's education. She thanks her correspondent for expressions of sympathy upon the death of her husband. She notes that her husband was a government servant, that in their marriage they were close, sharing joys and sorrows. She raised their children, looked after the property, and managed when he had to be away. When he fell ill, he worried about the family's future, but she was able to reassure him. She cared for him during his last days, going to his room to talk to him, or read to him when he became too weak. Now she was sorrowful, but it was a great solace to be able to write to caring friends. Mumtaz Ali comments that her education made it possible for her to have true companionship with her husband, to care for him and reassure him during his final illness, and to communicate with friends and relations in her bereavement. None of these things would have been possible had she been illiterate, and in that case, the death of her husband would have been an unmitigated disaster for all concerned.

The education of girls thus has to be as complete as that of boys, with, in addition, some special emphasis on their household roles. The question of textbooks then arises, for good textbooks in Urdu did not then exist in sufficient numbers. Mumtaz Ali recommends a number of books that are examples of good Urdu style as well as conveying useful information, among them the novels of Nazir Ahmad, Mirat ul-Arus, Taubat un-Nasuh, and Banat un-Na'ash, and Hali's Majalis un-Nissa. ${ }^{16}$ In

${ }^{16}$ Two of Nazir Ahmad's novels have been translated into English, Mirat ul-Arus as The Bride's Mirror, tr. by G. E. Ward (London, I903), and Taubat un-Nasuh as The 
Persian, Sa'di's Gulistan and Bostan are perennial favorites, as are a number of other ethical and historical works. As for Mir Amman's Chahar Darwesh (The Tale of Four Darweshes, also known as Bagho Bahar), Mumtaz Ali commends its pure and uncomplicated Urdu style, but questions whether the subject matter, romantic fantasy, is appropriate for either boys or girls. He nevertheless admits that, once the gates of Urdu literature are opened, the four darweshes are bound to enter. Rather than forbid such a book for girls, he opts for a tolerant attitude, noting that the risks of reading it are equal for young boys and girls. He also has some unkind words to say about the proliferation of novels in Urdu, opining that, while there are some novels that are true to life and raise the sense of social morality (such as those of Nazir Ahmad), ${ }^{17}$ other novelists write all sorts of romantic trash, filled with exaggerated language and feelings. ${ }^{18}$ Reading such novels results in false sophistication and superficiality. One may agree or disagree with Mumtaz Ali's literary tastes. Like other social critics of his time in other cultures, he was less concerned with aesthetic values in literature than with the idea that literature should be socially useful and morally edifying. ${ }^{19}$ One should not lose sight, however, of his main point: that the same standards should apply to literature whether the readers are men or women.

Mumtaz Ali also proposes several solutions to the problem of the paucity of Urdu reading materials for the education of women. First of all, he announces his plan to start publishing a newspaper specifically for girls and women, containing useful articles in clear Urdu style which will impart knowledge about the world for their education, and ideas for improved housekeeping, health care, etc. The editor will be a woman (his wife), and contributors will also be women. ${ }^{20}$ Secondly, he, together with a number of his friends, plans to form a committee to read all the available Urdu novels and to choose those that are most

Repentance of Nusooh, tr. by M. Kempson (London, 1884). I have translated Hali's Majalis un-Nissa and his poem, Chup ki Dad, into English, published as Voices of Silence (Delhi: Chanakya Publications, 1986).

17 'Every girl should desire her home to be like Asghari's (the heroine of Nazir Ahmad's Mirat ul-Arus); every girl should want her husband to be a tahsildar or a deputy collector.' HN, p. 55 .

18 'Our friend [Abdul Halim] Sharar uses every word he knows to describe his sorrowing hero. His heart's blood is squeezed out drop by drop; tears flow incessantly from his eyes.' Ibid.

${ }^{19}$ Tolstoy's essay, 'What is Art?' comes to mind as an example of this school of thought, but such views were a common theme in much Victorian writing.

${ }^{20}$ This refers, of course, to Tahzib un-Niswan, which began publication in July $\mathrm{I} 898$, shortly after the publication of $\mathrm{HN}$. 
beneficial and, possibly, review them in the newspaper mentioned above. In this way, good writers and edifying books will receive proper recognition and harmful books can be avoided. ${ }^{21}$ Thirdly, he proposes that schools for girls be started, but not on the pattern of government schools. Heretofore, girls' schools have emphasized the training of poor girls to be teachers. Training such ustanis (women teachers) performs a useful social service, but does nothing to raise the status of girls' education. Until the daughters of respectable (ashraf) families begin to get a proper education, public opinion will look down on girls' schools. Consequently, schools should be started in the homes of respectable families and should educate the daughters of that stratum of society. Mumtaz Ali here shows considerable sociological insight, and provides the rationale for a number of schools founded for the daughters of the ashraf during the following decade. ${ }^{22}$

\section{Purdah $^{23}$}

After his detour into proposals for women's education, Mumtaz Ali returns to his discussion of women's rights in Islamic law with an examination of purdah. He maintains that purdah, in the sense of modest behavior, is natural to human nature and characteristic of civilized societies, but that purdah as it is practiced among ashraf Muslims in India goes far beyond anything that the shari'at intended. Such customs have debilitating social results but, he admits, they are very difficult to dislodge. Arguing from verses in the Quran that refer to the need for modest behavior and from hadith in which the Prophet ruled on various aspects of behavior, Mumtaz Ali draws a clear separation between what is customary-and thus subject to changeand what is normative or desirable according to the shari' at. He does not argue for the abolition of purdah, but rather for a pattern of behavior that embodies shari ${ }^{6}$ t-inspired modesty, while allowing women greater

21 Mumtaz Ali does not mention it here, but his own publishing firm, the Dar ulIsha'iat-e-Punjab, became the publisher of didactic social novels, including works by Muhammadi Begam, Rashid ul-Khairi, Nazar Sajjad Haidar and others. For a good summary of this school of literature, see Shiasta Akhtar Banu Suhrawardy (Begam Ikramullah), A Critical Survey of the Development of the Urdu Novel and Short Story (London: Longmans, 1945), pp. ${ }_{105}-65$.

${ }^{22}$ For one such example, see Gail Minault, 'Shaikh Abdullah, Begam Abdullah, and Sharif Education for Girls at Aligarh,' in Imtiaz Ahmad (ed.), Modernization and Social Change among Muslims in India (Delhi: Manohar, 1983), pp. 207-36.

${ }^{23}$ This section summarizes HN, pp. 60-102. 
freedom of movement and social discourse, as befits their status as responsible human beings.

Of the Quranic verses that refer specifically to modest behavior, the first enjoins the believers to keep their eyes cast down and to cover their private parts. This injunction applies equally to men and women. It is followed by a verse that applies only to women, that they should keep their breasts covered and not parade their beauty and ornaments in public. Mumtaz Ali says that, apparently, women in ancient Arabia did not cover their breasts, and this verse was meant to change that immodest practice and to discourage other unnecessary flaunting of beauty and wealth. This was in line with the general requirement of modesty for all, but it was not meant to disable women. Another verse states that women should not go about everywhere as they did in the time of the jahiliyyat ('the time of ignorance,' i.e., before Islam). This verse refers to a specific time and place, as it enjoins Muslim women to be more modest in their behavior than women were in pre-Islamic times, but it does not imply that women should never leave their homes even for necessary tasks. Another verse advises the women of the Prophet's family and other Muslim women to wrap shawls about themselves when they go out, so they will not be harassed. This verse was revealed in Medina at a time when conditions were still unsettled, before Muslim law had been fully established. Muslim women hesitated to go out for fear of being teased by ill-mannered unbelievers. The revelation contained in this verse was meant to counteract this specific problem. Veiling with a shawl or chador was thus meant to give women greater mobility in a time of uncertainty, but did not mean that they should hide their faces. Nor did the verse imply that they should not go out at all.

Mumtaz Ali bolsters his reading of these Quranic verses by citing the views of Islamic jurists on the subject of purdah. He summarizes their views concerning what is lawful for men to see of unrelated women as follows: ( 1 ) The face and hands may be seen, but the rest of the body must be covered. Abu Hanifa, however, feels that the feet need not be covered, and Abu Yusuf feels that the lower arms may also be shown. (2) If a person is a lecher, he should not look upon unrelated women at all. (3) In this respect, Muslim and non-Muslim women should be treated the same. (4) The Prophet felt that a man should see the woman he intended to marry.

Mumtaz Ali then makes two related points. First, if the style of dress of the women of Delhi and Lucknow were reformed and made more 
modest, ${ }^{24}$ they would not be obliged to spend their lives within their four walls. They could then go out with their husbands or other relations while meeting all the conditions for modesty as outlined in the shari'at. Secondly, if a woman dresses and acts modestly as indicated above, and a man still looks at her lustfully, the sin is in the eye of the beholder. Why punish half the population because of a few lecherous characters? If a person covets the property of another, the covetous one should be disciplined. If a thief wishes to steal sweets, must the halwai close his shop, or the thief be reprimanded? The cure to lust lies not in locking up the women, but rather in self-discipline. The shari'at exempts neither men nor women from the responsibility for moral behavior, which is the true meaning of purdah. Mumtaz Ali, in this as in other matters, stresses equality between men and women.

Mumtaz Ali continues his discussion of purdah by dealing with several specific problems. The first problem is the kind of exaggerated purdah restriction that he feels is destructive of family life among Muslims in India. The example he gives is the question whether a woman should be seen by her husband's brothers, or-as is the case in sharif society in India-maintain total purdah before them. There is disagreement among Muslim jurists on the subject. For a solution to this question, he delves into the hadith, while pointing out that since the Prophet had no brothers, the only relevant traditions necessarily deal with cousins whom he treated like brothers, such as Zubair ibn Awam who was married to Asma bint Abi Bakr, who was also the sister of the Prophet's wife Ayesha. Asma was thus his sister-in-law in two ways ('brother's' wife and wife's sister). Mumtaz Ali finds a couple of traditions that mention the Prophet meeting Asma face to face when other people were present. He thus concludes that this particular barrier to family relations is unnecessary, that a woman may meet her husband's brothers, as long as others are present.

Another problem occurs when people admit that women do not have to be kept locked up in their homes, but then make exceptions for extraordinary circumstances-times of war or civil disorder, or times of revolutionary change, like the present. Mumtaz Ali responds to this by outlining three principles based on the Quran. The first is that actions can be classified as obligatory, permissible, and forbidden. If any

${ }^{24}$ The styles he objected to included short kurtis which left the midriff bare above the pajamas, very short sleeves, and diaphanous muslins which left very little of the female form to the imagination. He also took exception to the very long, very full pajamas which were immobilizing to women. $\mathrm{HN}$, pp. $77-8$. 
action is permissible but conditions require that it be undertaken with caution, it is still permitted. One should not, therefore, forbid women to go out simply because caution is required; to do so is unjust. The second principle is even stronger than the first. God's injunction concerning women who have sinned gravely or broken the law is that, if-upon the testimony of four witnesses - they are found guilty of a major offense, then they may be imprisoned. But God never intended that every woman and girl be imprisoned as if she were a criminal. Third, concerning the revolutionary or dangerous nature of the times, Mumtaz Ali notes that undesirable things happen in all times and places. But why is it that some men lock their women away, counter to God's injunctions? There can be only two possible explanations. The first is that the man believes the woman has such a bad character that she will misbehave if she comes into contact with other men. The second is that he believes all other men, including close friends and relations, are untrustworthy. When men in a given society are so mistrustful, there can be no true love, understanding, friendship, or justice in that society. A total breakdown of civilization is the result, a state of affairs that goes completely against the message and intent of the Prophet.

Mumtaz Ali concludes his discussion of purdah by pointing out the deleterious effects of extreme isolation on the women concerned. They do not get enough fresh air and sunshine and thus their health is affected. When they fall ill, they cannot see or be seen by a doctor, and thus adequate medical care is denied them. They are denied any experience of the outside world which would broaden their mental horizons and improve their education. They cannot visit famous historical buildings, museums, gardens, zoos, railroad stations. Women in such families who do travel, whether in closed palanquins, coaches, or trains, are sealed up behind blinds so that people will not see them, and neither can they see the world of nature as it passes by, not to mention the unhealthy effects of the stifling heat in such conveyances. And when these women have to change trains, a bevy of servants holds up curtains to shield them from all eyes. This is stupid, wasteful, and only serves to call attention to them. Women are kept in such extreme purdah that even the word 'wife' is in purdah. Instead of saying 'my wife,' a man will say something like 'the person in my house' or other circumlocution. This extreme form of purdah is not only injurious to women, but it harms the entire society, as it promotes narrow-mindedness and mistrust even among members of the same family.

To combat the deleterious effects of purdah upon women and upon 
the society, Mumtaz Ali recommends a number of changes, including the reform of women's dress and permission for women to go out of their homes to visit public places, to shop in the bazaar, and to attend public gatherings with their husbands. A burqa ${ }^{25}$ is sufficient covering for these outdoor activities, and the shari'at permits the face and hands to be uncovered. Though if a woman feels uncomfortable about showing her face, she may cover it. A doctor or a hakim should be able to examine a woman who is ill. A woman should not have to maintain purdah before her husband's male relations, nor a man be restricted from meeting his wife's female relations.

\section{Marriage $^{26}$}

Having established that women and men have equal rights and that women therefore must be educated and liberated from extreme purdah, Mumtaz Ali goes on in the next section of Huquq un-Niswan to discuss marriage. Islam attaches great importance to the institution of marriage, the aims of which are twofold: to insure the survival of the human race, and to provide human beings with companionship, happiness, and support. Children need greater care for longer than the offspring of other animal species, and thus the formation of stable families is essential for the survival of human society. But beyond the basic need for reproduction and survival is the need of adult humans for sympathy and companionship. Unless marriage fulfills both of these aims, God's purposes for a just society cannot be achieved.

Unfortunately, according to Mumtaz Ali, the Muslims of India do not adequately fulfill these two aims of marriage in practice. In the first instance, Muslims marry off their children at a very young age, when they are too young to make a free choice (also required by the Quran) and too young to understand the implications of the life commitment they are making. Further, young marriages mean that children soon become parents themselves, which is injurious to their health and to the health of their children. This damages the health and quality of the entire race and thus threatens the survival of Indian civilization. In the second place, human companionship is not fostered by a system in which boys and girls are married off with no say in the matter and no

${ }^{25}$ The burqa with a raisable face veil was a modern innovation, and by no means common when HN was published. Women's publications such as TN helped popularize it.

${ }^{26}$ This section summarizes $\mathrm{HN}$, pp. 102-42. 
understanding of what is at stake. Marriages are contracted by the parents for material considerations, with no attention to the future happiness of the individuals concerned. The beautiful daughter of a poor man will be married to the defective son of a rich man in order to earn a high mahr. Another daughter will be palmed off before she becomes a burden with no attention to the boy's education or morals or to the customs of his family. Two young people who really do care for each other will be kept apart by unreasonable dowry demands, and so on. This results in a lack of communication between spouses which is the cause of most of the quarrels and unhappiness in the society. In short, the Muslims have forgotten the true aims of marriage; they sacrifice young people to customary usage and embitter their lives.

Mumtaz Ali places tremendous emphasis on the need for marriage to be based on the consent of the individuals involved, but he is well aware that the 'consent' of the boy and girl, even after they have reached the age of discretion, is usually pro forma. The boy is cajoled into consent with the promise that if he does not like his bride, he can always marry again, but that usually proves to be economically impossible. A girl, brought up to accept her fate, is supposed to sit passively all during the marriage ceremonies, her eyes downcast, her lips mute. Thus her consent is usually simply assumed. This custom goes completely against the shari'at, for the Prophet decreed that a marriage contracted without the free consent of the partners was unlawful. But what is the solution? In a social system where purdah is so extreme that the young people have no chance of knowing one another, or of judging human nature and thus having any basis for choice, the chance for any meaningful consent would seem hopeless.

Mumtaz Ali has already shown, in the preceding section, that the extreme purdah practiced by sharif society also contravenes the shari at. He thus makes a number of suggestions for reforms that would improve the chances for free choice by the bride and groom and that would, consequently, also make for a greater understanding and friendship between the families of, and partners to, the marriage. (I) A girl who is of marriageable age should not be excluded from all the preparations going on in the clan of her marriage. This will have three beneficial results: Women in the family, possibly including those related to her betrothed, will be able to form a better judgement of her personality and her abilities; they will see to it that she is better prepared for the changes that are in store; and if there are any defects in her looks or abilities, they will be clear to all and this will not become an issue in the family later, after the marriage. (2) The girl's female relations should 
invite the women of the boy's family to their house for some social occasion (Mumtaz Ali suggests a majlis-e-maulud), ${ }^{27}$ so that they could all become better acquainted and thus produce a more welcoming atmosphere for the girl when she goes to her marital home. (3) If the girl is educated, it is not inappropriate for some writing in her hand to be shown to the boy. (4) If the parents of the two families are acquainted and have cordial relations, there should be some way to arrange for the boy to see the girl discreetly in order to have a better idea of what she is like. This would help fulfill the injunctions of the shari'at, and remove many of the difficulties of marriage. (5) A photograph of the girl might also fulfill this purpose.

(6) The girl, similarly, should have a chance to know what the boy looks like and what his character is like, perhaps through reports from her relations, and thus have a basis for her consent. (7) To assess the character of the boy, there are a number of points that the girl's family should consider: (a) What is the character of his father and other male relations? Are they upright? Or do they have the custom of taking second wives or concubines? (b) With what sort of people does he associate? Are they educated, pious, or wastrels and gamblers? (c) If he is educated, wh:at sorts of books does he read, ethical and religious works or trashy novels? (d) How does he occupy his time, in hard work and study, or in flying pigeons and kites? (e) What is the general assessment of the boy's character at his school or in his neighborhood? (f) How are the other women in the family treated? Are they treated like slaves, or with respect and understanding? (8) Before agreeing to the engagement, the girl's family should have a full assessment of the economic position of the boy's family. Whether he is rich or poor, they should know what to expect, and the girl should be prepared to cope.

(9) It is also necessary to reform the giving of mahr (dower). In Islamic law, the wife has a right to the payment of mahr by the husband, part of which is given upon marriage and part of which can be deferred. ${ }^{28}$ Parents often demand a huge mahr at the outset, in the hope that this will discourage divorce, but this only embitters family relationships. More beneficial, in terms of protecting the wife's interest, is

${ }^{27}$ majlis-e-maulud or milad: The commemoration of the Prophet's birth and a retelling, in song, of the major events of his life. This is a popular domestic ritual, especially among women, performed on the annual anniversary of the Prophet's birthday, but also on other happy occasions: an engagement, a birth, etc.

${ }^{28}$ The Hanafi school of law divides the mahr into prompt and deferred payments, the latter due upon termination of the marriage. Mumtaz Ali's recommendation differs only slightly from standard Hanafi prescription. Cf. John L. Esposito, Women in Muslim Family Law (Syracuse, NY: Syracuse University Press, 1982), pp. 24-6. 
the placing of stipulations in the marriage contract. For example, the husband would agree to pay a higher amount only in the event of divorce or a second marriage, and the wife would agree not to demand payment except under such conditions. In this way, there would be a mutual understanding, and both partners would benefit. The wife would have security without demanding a ruinous mahr, and the husband would know that he would not be liable to a high payment except under certain specific conditions. Other stipulations in the marriage contract can limit polygamy and give the wife more control over her fate, i.e., the husband would agree to give his wife the right to divorce if he takes a second wife. She thus retains the right to mahr, but also the right to initiate the divorce under certain conditions. Other reforms to mahr might include the postponement of the entire payment, so that the parents of the bride do not get their hands on the mahr and thus profit unlawfully from their daughter's marriage. In addition, other systems of payment can be divised to ease the strain on the husband. For example, a government servant, with a regular salary but no inheritance, could set aside a fixed proportion of his monthly income as mahr. These suggested reforms are fully in line with the shari'at. Some benefit the wife, some the husband, but all emphasize the need for mutual agreement and equality in contractual dealings which, Mumtaz Ali maintains, are absolutely necessary to insure equitable and happy marriages based on the free choice of the partners.

(10) Mumtaz Ali also suggests a reform of the custom of dowry. Parents give their daughter household goods, vessels, cutlery, bedding, lavish clothing, and frequently also furniture. They prepare the dowry for several years in advance and carry it all to her new home in procession with great pomp and show. The wasteful expenditure on dowry has reached ridiculous proportions. It is hard to decide, Mumtaz Ali notes, whether the purpose of all this is to please the recipient or to drown her. A few useful household items and a few new clothes are quite sufficient. The rest of the dowry should be given in the form of money or securities or the right to income from some land, funds which would be under the bride's control and used for some agreed purpose. The emphasis is, again, upon moderation, the reform of wasteful custom, and the need for agreement between families and marriage partners.

Mumtaz Ali continues in this vein while discussing the process of negotiations and engagement leading up to the marriage ceremony itself. The negotiations should be friendly and straightforward-no coy refusals hoping that the other party will renew the proposal with higher 
stakes. During the period of engagement, the families should maintain friendly social relations and allow the engaged couple to correspond. This is the civilized way to behave and will assure that the marriage is, truly, an occasion for happiness (shadi: marriage/happiness). At the time of the marriage, wasteful expenditure on useless customs should be avoided, although Mumtaz Ali recommends moderation, not stinginess. In the barat (groom's procession), close relations and friends are sufficient; there is no need to assemble an army. The boy can be mounted on a horse, but those accompanying him should be on foot. It is sufficient for him to be dressed in somewhat better attire than normal, with perhaps a garland of flowers, but heavy brocade clothing is against the shari'at. The girl's family may decorate their home tastefully with flowers and lights for the occasion, but this should not be lavish or excessive. He further recommends that the bride, attired in such purdah clothing as her relatives feel is appropriate, should participate in the nikah ceremony and give her assent personally before the qadi. When the bride goes to her husband's home, she should not be wrapped up like a package and carried, constantly surrounded by a crowd all talking at once. Rather she should walk on her own, ride in modest attire, be able to respond to questions as a human being (not act like some dumb buffalo), and generally be able to adjust to conditions in her new home like a normal person.

\section{Relations between Spouses ${ }^{29}$}

Mumtaz Ali's approach to marriage emphasizes close adherence to Islamic law and a straightforward approach to human relations, based on mutual respect between men and women and understanding between the families concerned. Such considerations carry over into the final section of Huquq un-Niswan, the discussion of relations between spouses. When men recognize that women's rights in Islamic law are equal to their own, and grant them an education commensurate with their abilities, then it will not be necessary to consider the problem of marital relations, maintains Mumtaz Ali, since the problem will disappear of itself. But that is not currently the case. In the section on women's education, he made the point that an educated man cannot be happy with an uneducated woman. Women's education, however, is still in a rudimentary state, so lack of communication between spouses

29 This section summarizes $H N$, pp. $142-88$. 
is bound to result. One solution is that the husband may try to educate his wife and thus bring about some mutual understanding. But she must respond to his coaching, otherwise he will lose interest. The result in that case is similar to that of a man who takes great interest in household decoration or in the attractive clothing of his wife, and yet his wife takes no cognizance of her husband's taste and neglects her own appearance. In other words, both partners are responsible for working toward compatibility, otherwise they cannot truly be husband and wife, but only mates in the most basic sense. The only cure for such basic incompatibility is more careful choice before marriage.

Other frequent causes of misunderstanding between husband and wife, however, are curable. A husband who is inconsiderate, who does not trust his wife to manage household expenses, who constantly pesters his wife to excuse him from payment of mahr, or who resents it if his wife is educated, should see the error of his ways and show more consideration. She may never complain, and yet her life will be embittered, and the husband will have to answer to God for such unjust behavior. Another frequent source of misunderstanding is the motherin-law. It is an old adage that the mother-in-law and the daughter-inlaw cannot get along. There are many reasons for their quarrels, but the basic reason is that the mother-in-law and other in-laws want the daughter-in-law to serve them rather than her husband. And the husband, if he is dependent upon them, cannot say anything. The only real solution for this is to establish separate living quarters, but sometimes this is not possible. Parents, when marrying their daughters, should thus make sure that the boy is earning a living, in order to be able to establish separate living quarters if necessary.

A third cause of misunderstanding comes from the side of the girl's family. They cajole her to come home for long visits and make her feel guilty if she prefers to stay with her husband. They should realize that the wife's first priority is to stay with her husband and to love him more than her own family. Sometimes, when a family gives their daughter in marriage and she is mistreated, they will take a daughter from the other family and mistreat her in turn. Such behavior is doubly unjust, for two wrongs do not make a right. Other problems arise when a poor girl marries into a rich family, or vice versa. Mumtaz Ali follows Muslim legal authorities in thinking that equality of social and economic status between spouses is more conducive to understanding and happiness.

The worst sort of misunderstanding arises, however, from the fact that the partners to the marriage are given no choice in the matter-a theme that Mumtaz Ali has emphasized before-and thus they do not 
have any expectation of happiness. Educated and respectable men, who should be more enlightened, treat their wives no better than brood mares or slaves. They come home only to eat and sleep. They always speak severely so that their wives are in constant fear of them. They order good quality food for themselves and their male relatives and friends, and poor quality food for the women of the household. They have ice and fans in the men's quarters during the hot weather, but no such comforts for the zanana, and so on. The cure for all these injustices is for the men to become more enlightened and realize that their wives are human too. Until women are treated like human beings, it is no use blaming them for not living up to their human potential. Mumtaz Ali, who heretofore has emphasized mutual responsibility for improving marital relationships, here places the greater responsibility upon the men for bringing about social change. He also emphasizes that simply talking about the need for change in public is not enough; men must begin by setting an example in their private lives. Educated men, government servants, professionals and the like who talk about the need for self-government in India should realize the connection: Before they grant greater rights to their women, how can they, in all seriousness, demand greater self-determination for themselves?

The educated sections of the community, therefore, must lead the way in granting greater rights to their women and in re-enforcing the shari'at, which has been forgotten. One of the legal reforms that Mumtaz Ali advocates is the passage of a divorce law that recognizes Muslim women's rights to initiate divorce (khula). This right is present in the shari'at, provided the woman gives up her right to the payment of mahr, but is not in force in India. He thus anticipates by some forty years the Dissolution of Muslim Marriages Act of $1939 .{ }^{30}$

Mumtaz Ali completes his discussion of marital relations by laying out a series of principles which, if observed by the spouses, will result in mutual happiness. His emphasis, as throughout the work, is upon an equitable relationship between men and women, and in this case, an equitable balance of rights and duties. The tendency in Muslim marriage has been for the man to claim all the rights and for the woman to assume all the duties. His advice to men, therefore, is that they have certain obligations toward their wives. For example, the husband should not begrudge his wife nice clothing and ornaments, within their

\footnotetext{
30 This act, among other things, was intended to 'consolidate and clarify the provisions of Muslim law relating to suits for dissolution of marriage by women,' and established additional grounds for divorce which were not recognized in the Hanafi school. Esposito, Women in Muslim Family Law, p. 78.
} 
means. He should give his wife adequate money for household expenses and receive an accounting for it, without accusing her of wasting it. $\mathrm{He}$ should trust his wife, as mistrust is the basis of a great deal of bitterness in marriage. He should not test her love by asking her to sacrifice her ornaments to meet a sudden expense. Such demands are inappropriate. If some disagreement arises, they should not quarrel in front of the servants or other women of the household, as this will humiliate his wife; rather they should discuss the matter in private. The women servants in the household should be under the supervision of the wife, and the husband should not interfere, give the maid servants extra orders or, worst of all, have illegitimate children by them. Neither husband nor wife should ask the other to stop seeing his or her own relatives. It is clearly unjust to ask the other to do something one would be unwilling to do oneself. When they quarrel, the husband may ask: 'If I am so bad, why did you agree to marry me?' Or the wife may ask: 'Why didn't you marry someone else?' These sorts of questions are sinful and should be avoided at all costs. Husbands and wives are bound to disagree from time to time, but one should not cast aspersions on the agreement made by both partners and their families in the sight of God. If the husband's first wife has died and he has remarried, he should never compare his present wife to his first one, nor praise the first wife in front of his present one. Such comparisons arouse jealousies and touch sensitivities that are natural, but that should not be aggravated. Finally, the husband should not go out, shamelessly seeking his pleasure elsewhere, relying on the long-suffering patience of his wife. He should realize that God is on the side of the patient ones and has given them rights too.

As for the wife, she, too, should follow certain basic principles in order to assure domestic happiness. Having emphasized her rights while giving advice to her husband, Mumtaz Ali now emphasizes her duties toward him. Her duties included obedience, respect, and affection. Obedience to the husband is absolutely necessary, even if he is oppressive. Mumtaz Ali gives as an example the husband who forbade his wife to visit her mother, even though the latter was on her death bed. When her mother died, he forbade her to join the funeral procession, and yet she remained obedient to her husband. Mumtaz Ali had already advised husbands against such behavior, so he clearly feels that it is unjust, and yet he here commends unquestioning obedience on the part of the wife. Further, the wife should obey without showing displeasure, only drawing the line when obedience to the husband goes against God's commandments. She can fast and pray without her 
husband's permission, as that involves obedience to a higher authority. Second to obedience comes respect for the husband. Some women respect their husbands to their face but then complain about them behind their backs. That is no way to behave. Again, if there is disagreement, she should not confront him in public but treat the matter diplomatically and in private.

Love and affection are even more necessary than obedience and respect in Mumtaz Ali's opinion. The wife's every action should be governed by affection for her husband, and taken with a view to easing his worries and cares. When she marries and comes to his home, her first priority should be to learn his habits, his likes and dislikes, and always try to do what pleases him. Another sign of affection involves keeping secrets. She should never reveal what he tells her in confidence. Capable housekeeping is also a sign of love and care for him: good cooking, skilful sewing, neatness and cleanliness should all be habitual for her. She should not be too dependent upon the servants in these matters, but know how to do things herself and thus be able to control and manage all that goes on in the household. And though supervision of the servants is her domain, she should always consult her husband before hiring or firing a servant. She should be moderate in her expenditures, neither extravagant nor stingy. She should be hospitable, making guests feel welcome, within her means. She should not be envious of women who have more than she, but keep in mind her husband's earnings, for earning is difficult but spending is all too easy. If her husband asks her to do something, she should always do it cheerfully and promptly. Postponing things because she is feeling tired or reluctant will not make the tasks any easier and will only result in her husband's displeasure. Finally, if she should displease her husband in any way, she should not be too proud to ask his forgiveness.

Mumtaz Ali concludes by saying that if women cultivate the virtues of obedience, respect, and love, then their husbands will surely develop the same virtues. If the wife respects her husband and is obedient, then he will respect her and obey her wishes as well. If she loves him sincerely, then he will reciprocate her affections.

\section{Conclusion}

Mumtaz Ali's Huquq un-Niswan is an outspoken advocacy of women's rights in Islam and in Muslim family life. It is an amalgam of Quran and hadith scholarship, recommendations for reform of individual 
behavior based on Islamic law, social observation, and personal advice. Works of religious advice, advocating reform from a variety of points of view, were not at all unusual in the late nineteenth century, ${ }^{31}$ but Mumtaz Ali's work is unique for its egalitarian attitude toward human relations. His Urdu style is clear and unadorned, not designed to impress others with his erudition in Arabic and Persian, but rather to appeal to those who were literate but not highly learned, including women. His arguments are logical, his examples gleaned from the prophetic tradition or from the actual behavior of his friends and relations. One may differ with him over certain details, but his overall argument is unassailable: Women are granted rights in Islam that are denied to them in practice. He attacks a host of customs and traditions which he regards as un-Islamic and oppressive to women. His aim is to acquaint women with their rights, and to get men to recognize women's equal status as human beings and change their behavior toward them. It is one thing, however, to accept the intellectual basis of his argument, and it is quite another to change one's intimate behavior. Mumtaz Ali concludes on an optimistic note which seems unjustified in retrospect. His work was received with hostility or-which is perhaps worseapathy. The initial printing of Iooo copies by his own publishing firm, the Dar ul-Isha'iat-e-Punjab in Lahore, was never repeated. Huquq unNiswan was undoubtedly too far in advance of its times. Given the current debate about the importance of Muslim personal law reform, however, it is well to remember this early champion of women's rights in the shari'at.

31 The Deobandis and Ahl-e-Hadith carried out a pamphlet war at that time, and works of religious advice were frequent phenomena all over India after the advent of the printing press. See Metcalf, Islamic Revival, pp. I99-2 I 5 ; and Rafiuddin Ahmed, The Bengal Muslims, $187^{I-1906}$ (New Delhi: Oxford University Press, I981), pp. 84-1 06. 